\title{
Representing Palestinian Dispossession: Land, Property and Photography in the Settler Colony
}

\author{
Brenna Bhandar and Alberto Toscano
}

\begin{abstract}
This article explores the centrality of property and dispossession to the operations of settler-colonialism in Israel/Palestine through the prism of Edward Said and Jean Mohr's collaborative photographic essay After the Last Sky. Drawing on the way in which Said directs our attention to the meanings of land, place and exile within Palestinian life and resistance, and putting his writing in dialogue with recent photographic projects that focus on Palestinian dispossession, the article brings these theoretical perspectives to bear on the present reality of the dispossession of Palestinian Bedouin in the Naqab village of Al-Araqib.
\end{abstract}

\section{Introduction}

Property and dispossession should sit squarely at the centre of any critical understanding of the on-going reality of settler-colonialism. This relates not just to the way in which settler-colonialism is to be understood as a crucial variant of the accumulation by dispossession that has accompanied the history of capitalism, ${ }^{1}$ but also in terms of the less visible life-worlds and ideologies of ownership and dispossession that subtend the everyday life of the settler colony and resistance to it. As Frantz Fanon and others have taught us, the very categories of settler and native are forged in the colonial context through the prism of property ownership and related conceptions of propriety and the proper. ${ }^{2}$ This article returns to Edward Said's landmark collaboration with the Swiss photographer Jean Mohr, After the Last Sky, in order to consider some of the ways in which Said and Mohr combined a critique of dominant representations of Palestinian dispossession with an oppositional practice of representation, with special attention to the place of land, memory and property in their work. ${ }^{3}$ It also examines whether, in contrast and counterpoint to the colonial uses of photography as an apparatus of classification and control, certain photographic practices can play what Said called a 'potentially insurrectionary" ${ }^{4}$ role in projects of decolonisation.

The complex web of legal, social, economic, psychic and political relations that receive the name of 'property' are represented in Said and Mohr's book in ways that not only radically augment our understanding of the life-world of dispossession, but also challenge the legal representation of settler colonialism by showing how, first, the way in memory of the colonised can counter modern conceptions of ownership; second, that resistance to settler-colonialism can challenge the temporality of displacement as conceived of by the law; third, how visual representation in both photography and film has performed a crucial role in developing a different political imaginary and consciousness when it comes to resisting dispossession. In what follows, we also try to reflect on how Said and Mohr's political method of montage and commentary can help to reframe legal critiques of dispossession in Israel/Palestine, as well as to reconsider the specific ways in which the politics of representation plays out in that context. Our contemporary counterpoint with Said and Mohr - with reference both to property and to photography - will be the struggle of the Bedouin of the Naqab/Negev against the ongoing project to displace, resettle and erase them from the land - a process in which photographic images can serve as forms of legal evidence, military instruments or complex 'events' in which relations beyond those of appropriation and dispossession, and beyond the juridical frame, may become partially visible. We thus begin with this present context of settler-colonial dispossession, to then turn to After the Last Sky for a 
visual interrogation of the nexus of property, law, and the politics of dispossession.

\section{Living in 'dead' land}

In June 2014, members of the al-Uqbi family presented an appeal to the Supreme Court of Israel for the recognition of their ownership rights over land they have inhabited for hundreds of years. The appeal was in response to a District Court judgment that dismissed their claims on the grounds that the land was validly expropriated pursuant to the Land Acquisition (Validation of Acts and Compensation) Law 5713-1953, on the basis that it was mawat, or 'dead' land. ${ }^{5}$

The mawat or 'dead land' doctrine originates in Ottoman land law, was adopted by the British during the Mandate, and continues post-1948 as a key component of Israeli land law. Many scholars have remarked upon the ways in which the spirit of the Ottoman doctrine has been transfigured in its contemporary iteration, with the purpose of ignoring the historic presence of Bedouin on their lands prior to the establishment of the State of Israel, or indeed, during the periods of Ottoman and British rule. Kedar, Yiftachel and Amara thoroughly deconstruct what they refer to as the 'Dead Negev Doctrine', bringing new evidence to light in their analysis of how the Israeli state 'manipulates Ottoman and British land law' to appropriate Bedouin land and deny the legitimacy of Bedouin land claims. ${ }^{6}$

At trial in the al-Uqbi case, the plaintiff/appellants argued that the state designation of their land as mawat was incorrect, on three different grounds. First, until the beginning of the $20^{\text {th }}$ century, the Ottoman doctrine was not applied to their lands; rather, the Ottoman Authorities and the British recognised Bedouin legal autonomy. Second, they argued in the alternative that the status of the disputed lands in 1858 (when Ottoman Land law was in force) would be appropriately designated as miri land, because the land was settled and cultivated. ${ }^{7}$ Finally, they affirmed that the purchase of lands by Jews and Arabs from the Bedouin proves that they owned the land, while tax records maintained by the British during the mandate also demonstrate that Bedouin ownership of the land was not in question prior to 1948.

The outright and absolute rejection of the al-Uqbi claim, which follows numerous other precedents in Israel (where no Bedouin cases involving land title have been successful), contrasts with the partial legal recognition of Indigenous rights in other jurisdictions. Unlike their counterparts in Canada, Australia, and elsewhere, the Israeli judiciary seems intent on refusing to acknowledge even the faintest ambiguity or exception in their rendition of the history of land-use and occupation in the Negev. If today's dissenting judgments are tomorrow's majority rulings - as optimistic jurisprudents often like to remind themselves - it is difficult, at the present moment, to imagine Israeli case law on the rights of the Bedouin taking a different course, regardless of the demands of justice. The conceptualisation of the legal tests to establish a land right in the case of the Bedouin reflects a legal formalism and positivism that works to deny the complex history of the Bedouin in the Naqab, as well as their political and legal relationships to successive waves of occupying forces and changing modes of government.

The al-Uqbi family has relied on an ample range of evidence and testimony to prove their ownership, including maps of varying provenance, tax records, the expert testimony of anthropologists and geographers, and photographs of the area (to which we return in the conclusion). These "material witnesses" ${ }^{8}$ and the experts who frame and interpret them have been harnessed in order to establish the facts necessary to prove a claim of ownership. In the case of al-Uqbi, aerial photographs taken of the claim areas in 1945 by a British RAF serviceman were utilised to prove the existence of cultivation on areas of the lands claimed. The difference in interpretation of the photographs between 
Justice Sarah Dovrat, as set out in her findings, and Professor Oren Yiftachel, expert witness for the Plaintiffs, reflects the wide gulf between a Bedouin 'point of view' regarding what constitutes cultivation and settlement (something that Yiftachel has characterised as 'semi-nomadic') and that of the State.'

\section{Land, memory and property in After The Last Sky}

In maintaining the myth that the Naqab/Negev was a land without a people (at least not one fulfilling a standard of 'improvement' that Zionism inherited from the possessive individualist ideology of the British empire), the Court could be seen to perform the role of chronicler for the settler-colonial state, redacting the Bedouin presence on the land and imposing a seemingly abstract juridical gaze that relegates the dispossession of the alUqbi clan and others to the far margins of legal consciousness.

As we will explore below, the power of interpretation wielded by the Court and its judicial determination of the legal meaning of the aerial photographs could be usefully approached as a 'photographic event', in the sense articulated by the Israeli philosopher and theorist of photography Ariella Azoulay. Reflecting on her painstaking analysis of over 200 photographs of the Nakba that had been preserved in Israeli state archives for over 60 years, Azoulay writes:

I was sometimes disturbed by the fact that after working for a few days with one or two photographs, and finally succeeding in reconstructing what I was initially unable to read in them, I felt my efforts didn't lead to an account substantially different from that which an honest chronicler would have attached before filing them away. It was not due to chance, however, that such accounts or traces of that chronicler were absent from the photographs, nor would they have been mere additions to them. They were, rather, essential aspects of the photographic event - as opposed to the event photographed... The absence of such an account would therefore be part of what concerns me when reading these photographs, and distinguishes it, of course, from what that chronicler could, hypothetically, have documented, but didn't. ${ }^{10}$

What is the relationship between the legal dimensions of dispossession and their visual representation? How might the photographic chronicling of dispossession allow us to see and understand the life-worlds of ownership and dispossession that bleed out beyond the legal narrative and juridical framework of land ownership?

In After the Last Sky, in the chapter titled 'Emergence', Said recounts many of the primary legal and political techniques that have been used to dispossess Palestinians from their land. In response to the Zionist claim that there were no Palestinians, but at best un-rooted Arabs, on the land (people perhaps, but not a people) - a claim that is a barely veiled reiteration of the terra nullius mentality asserted by English colonists a century or two earlier in Australia and elsewhere - Said insists on the fact of presence. It is the 'slow accumulation of land by a policy of [Benthamite] detail' that has gradually 'blotted-out' the natives. ${ }^{11}$ He proceeds to give us the facts and statistics of Palestinian and Jewish land holding both prior to 1948 and after, and mentions the keystone policies that were used to appropriate Palestinian land: the infamous Absentee Property Law; land-use planning law, in the shape of the refusal of permits to further develop existing property holdings; deprivation of basic infrastructure, such as running water and electricity; and of course, control over the mobility of Palestinians, which makes it impossible for them to join the labour-market on equal terms or, most importantly, to access their land. ${ }^{12}$

Said's description of the legal mechanisms of dispossession sits opposite a photograph taken by Jean Mohr in 1983 of a Palestinian woman in the Rashidyé refugee camp in Tyre, South Lebanon, a generous smile revealing a missing tooth. ${ }^{13}$ Said wonders why it is that the prior presence of these natives on the land has failed to impress people around the world. Like other Indigenous communities, in the gaze of 
colonial powers they are perpetually caught on the threshold of modernity, frequently figured as 'vanishing races'. Against the multiple erasures, disavowals, marginalisations and 'blottings-out' that play such an integral part in the political aesthetic of settlercolonialism, the collaboration between Mohr and Said in After the Last Sky presents us with a series of radical interruptions of (and supplements to) the juridical framing of dispossession.

Much time has passed and the dynamics of dispossession have mutated, and arguably intensified, since the book's composition. After the Last Sky was first published in 1986, one year before the beginning of the first Intifada and several years before the Oslo Accords. It was published before the Israeli Security Fence - also known as the Apartheid Wall - began to scar the landscape. The book was authored more than 20 years before the UN Committee on the Elimination of Racial Discrimination would conclude that Israel is engaging in apartheid practices, in violation of yet more international laws. The breadth of images in After the Last Sky stretches across historic Palestine and the diaspora (a term Said problematises), reflecting a political unity that the geo-spatial fragmentation of the post-Oslo situation would make nigh-on impossible, and which contemporary conflicts, especially the Syrian Civil War, with its disastrous impact on Palestinian refugees, only exacerbate. The book can thus be seen to contribute to a political imaginary that is seeing a recent resurgence - as Palestinian activists and scholars insist that any move towards freedom must begin with 1948. This means thinking the present through the expulsion, exile and displacement of the Nakba, prolonged in the years between ' 48 and ' 67 through an array of techniques of dispossession, as well as a politics of accommodation on the part of some Palestinian elites resident within the newly-established (if wilfully indefinite) borders of Israel. ${ }^{14}$

Said writes, as he also does in his memoirs and elsewhere, of the way in which Palestine is kept alive and produced through memory. He observes that 'the stability of geography and the continuity of land - have completely disappeared from his life and the life of all Palestinians.'. ${ }^{15}$ Those images that testify to attachments to the land severed by the occupation, and indeed, those images that attest to a continued presence on the land, can thus be seen as keeping the claims of Palestinian ownership and belonging alive and visible. When the arsenal of legal and military strategies used by the Israeli state has meant the literal erasure of the Palestinian presence on the land, images such as the photographs depicting 're-settled' Bedouin (here referred to as 'nomads') in a modern apartment, illuminate the displacement and reveal an artefact of a past life that continues its existence in another form. As the caption tells us, with a ring of romanticism: 'Some years ago, these people still lived in a tent, under the desert sky. The carpet on the ground is the only remainder of that period'. ${ }^{16}$

The Prawer Plan, which seeks to intensify and complete the moving of Naqab Bedouin into reservation-like planned towns, and to confiscate their land for Israeli settlement, has gained a fair bit of traction in the international media, and elicited impressive resistance over the last couple of years. The Plan, indefinitely suspended for the time being, aims to inaugurate a new phase in well-established and on-going discrimination against this native population. The treatment of the Bedouin as somehow pre-modern is rooted, ostensibly, in the fact that they are semi-nomadic, and cultivate the land for subsistence purposes. ${ }^{17}$ They are also a largely pastoralist community. In order to modernize them, or to attempt to turn them, in the words of Moshe Dayan at the time of his tenure as Israeli Minister of Agriculture, into an 'urban proletariat' (rarely has Marx's 'so-called primitive accumulation' been more cynically articulated as a state strategy), ${ }^{18}$ the Israeli state has pursued a plan of sedentarization; confiscating the major part of the Bedouin's traditional lands and confining them to small villages.

Related to this is a perceived need to contain a demographic threat. Alongside 
ultra-Orthodox Jewish communities, the Bedouin have the largest natural population growth-rate in Israel/Palestine. The imperative to attain a Jewish demographic majority in the territory has been achieved primarily through planning laws. For instance, the 1965 Planning and Construction Law created regional planning bodies that did not acknowledge the existence of Bedouin villages in their master plans. ${ }^{19}$ In not recognising the existence of Bedouin communities and encampments, the master plans enabled the state authorities to zone their land as agricultural or military, rather than residential. Through this zoning process, the Bedouin were rendered 'illegal' and on this basis denied access to basic governmental services, such as electricity and running water, schools, and other infrastructure. The so-called unrecognised villages of the Bedouin have been subject to repeated demolitions by the Israeli state.

In the first chapter of After the Last Sky, entitled 'States', there is a full-page image, captioned 'Bedouin encampment near Beersheba, 1979'. ${ }^{20}$ Two-thirds of the image are taken up by a makeshift tent shading a swaddled baby, while at some distance in the fields behind, behind a bale, a woman (perhaps the child's mother, or a relative) can be seen hunched over the ground. Though no doubt it would be thrown out of court as evidence of occupation or cultivation, this image powerfully asserts the fact of Bedouin presence on the land. At the 'evidentiary' level, we can see from the furrows in the field the cultivation of the land (the image is intentionally cropped to remove any horizon, and one could easily imagine that a rising or turning gaze would almost immediately hit upon a sign of dispossession or domination). Symbolically, in the precarious entwining of land and birth, the image of the sleeping baby in the tent speaks to a way of life that has continued for generations.

Memory which, through such figurations and the experiences that underlie them, attests to prior relationships to the land can also be seen to work against modern concepts of property that define ownership on the basis of title deeds and interests registered in state archives. These images serve as propositions, affirmations of presence, which supplement the missing title deeds and evoke different conceptions of ownership and social relations, ones rooted in a period of time that preceded the Nakba of 1948.

As Patrick Wolfe writes with regard to settler colonialism, 'invasion is a structure, not an event ${ }^{21}$; or, to put it in another way, it is a continually unfolding event that does not reach an end point. Within the juridical sphere, the history of displacement and oppression endured by indigenous peoples has been dealt with through the political objective of reconciliation. In Canada for instance, reconciliation as a political and policy objective has been raised to the level of a constitutional principle. The Truth and Reconciliation Commission of Canada recently released its final report on the painful legacies of the Indian Residential Schools system, putting forward a number of recommendations for the government to heed. ${ }^{22}$ The temporality underlying the judicial and policy pronouncements on reconciliation are clear - past harms have a legacy that continues on into the present, and reconciliation provides a means through which these can be laid to rest in order to move towards a more just future. ${ }^{23}$

The reality of dispossession however is anything but linear. Not only is it a continuous if uneven process, but in the Palestinian context, successive attempts to render the Palestinian presence on the land invisible invariably result in a state of affairs that could appear as a cycle or better a spiral in its combination of repetition and intensification - dispossession, displacement, and the destruction and reconstruction of entire villages and camps.

Jurisdiction is, particularly after Oslo, fragmented and unstable. The legal status of Area $\mathrm{C}$ in the West Bank is contested and changing; the Israeli Supreme Court maintains the position that the Geneva Conventions do not apply to the West Bank and Gaza, as the Knesset has not incorporated the Conventions into domestic legislation. 
The Wall's rationale has produced yet more geo-spatial absurdity, with communities being torn apart, unable to access schools or businesses from their homes. The degree of spatial fragmentation does not permit lives lived according to a predictable horizon of expectations, but rather, a permanent temporariness, a term used by many to describe the conditions faced by Palestinians living in the West Bank and Gaza, within Israel, refugee populations, and others living in exile.

Viewed on this backdrop of temporal, spatial and political fragmentation, the images and text in After the Last Sky interrupt the myth of a linear temporality of dispossession, and like some of the works of fiction that Said discusses - namely Ghassan Kanafani's unsparing tale Men in the Sun - strive toward a form that 'might overcome the almost metaphysical impossibility of representing the present', ${ }^{24}$ whilst assuming the political and existential fact of interruption that runs through the Palestinian experience. They aim to create a continuity (that of everyday life and national liberation) precisely where Israeli settler-colonialism imposes fragmentation, while at the same time seeking to interrupt the continuity of that very settler-colonial project.

As Said remarked in Culture \& Imperialism, land is the principal prize in the politics imperialism and colonisation. ${ }^{25}$ We can see that photography, and also film, can fulfil a crucial function in refusing the ideologies of elimination and the nationalist narratives in which legal technologies of dispossession are embedded. They also constitute a form of knowledge that presents us with alternate political imaginaries, ones in which the affective and emotional consequences of displacement can be addressed and dealt with in some fashion.

In the second chapter, 'Interiors', Said conveys his need for restitution and recognition in a reflection on the specific character of his mother's dispossession. The tearing up of her passport by Israeli authorities when she married, as her legal and political status was to be subsumed under that of her husband, spoke volumes about the gendered and patriarchal nature of colonial rule. He then recounts the plot of a Palestinian film directed by Michel Khleifi, The Fertile Memory, in which an old woman's relationship to the land is dramatized. She refuses to accept attempts by Israeli settlers to legalise the dispossession of her land (to which she holds the title deeds) by paying for it.

\footnotetext{
Somehow, Khleifi has managed in his film to record Farah's first visit to her land. We see her step tentatively onto a field; then she turns around slowly with arms outstretched. A look of puzzled serenity comes over her face. There is a little hint on it of pride in ownership. The film unobtrusively registers the fact that she is there on her land, which is also there; as for the circumstances intervening between these two facts, we remember the useless title deed and Israeli possession, neither of which is actually visible. Immediately then we realize that what we see on the screen, or in any picture representing the solidity of Palestinians in the interior, is only that, a utopian image making possible a connection between Palestinian individuals and Palestinian land. ${ }^{26}$
}

These utopian moments create a space for imagining how life could be otherwise by working against the confines of property relations in and beyond the settler colony. The condition for such imaginings, and for not allowing them to slip into the false comforts of nationalist ideology (of which Said was an insistent critic), is a nuanced exploration of the politics and practice of representation, to which we now turn.

\section{Can they be represented?, or, The missing captions}

Among the pleasures of After the Last Sky is beholding how one of the most sophisticated and influential contemporary thinkers of the politics of representation tackles this question with respect to a medium - photography - quite marginal to his primarily literary and historiographic concerns (though we should not ignore the book that preceded After the Last Sky, Covering Islam). ${ }^{27}$ Even more arresting perhaps is that After the 
Last Sky, as Said's introduction recounts, was occasioned by a very concrete problem of representation, which neatly encapsulates the kind of image-economy which Said and Mohr sought to counter with this project - especially in what regards the stigmatisation and erasure of Palestinian everyday life in conditions of dispossession and exile. Mohr, at Said's recommendation, had been hired by the United Nations to produce a series of photographs of Palestinians to be exhibited in the entrance hall of the building in Geneva where the International Conference on the Question of Palestine - for which Said was serving as advisor - was to be held. Bowing to pressure - principally it appears from Arab governments traditionally hostile to non-instrumentalisable affirmations of Palestinian autonomy - it was decided that the Swiss photographer's images could be shown, but with no captions, no writing other than the most minimal indication of where they had been taken. ${ }^{28} \mathrm{~A}$ number of remarks can be made about this instructive incident.

The first, ironic and biographical, is that Palestine had been the scene of Mohr's contingent initiation into photography - himself an exile from Germany, he had gone in 1949 to work as a delegate of the International Red Cross with Palestinian refugees expelled from their homes and 'temporarily' resettled in the West Bank and Jordan. His long-time collaborator John Berger puts it thus: 'He began to take pictures so as not to forget the unpredictable and incongruous details - often painful, sometimes desperate, occasionally illuminating - concerning the lives he was witnessing. ${ }^{29}$ Mohr would go on to work for UN agencies, fashioning a curious career outside the urgencies of photojournalism and the prevalent modernist parameters of art photography, and developing a unique practice along with Berger, including works of rare ethical, political and aesthetic power, like $A$ Seventh Man and Another Way of Telling. ${ }^{30}$

It was reviewing the latter book in The Nation that, a year before the UN exhibition, Said celebrated Berger and Mohr's capacity to weave text and image in such a way as to replace narrative with 'constellations of experience (what Gerald Manley Hopkins would have called bursts of meaning)'. ${ }^{31}$ Said stressed - in a way that obviously prefigures the montage of After the Last Sky - the way in which their work was subtended by 'an argument against linear sequence', ${ }^{32}$ which sought to restate both the ambiguity and the 'potentially insurrectionary' ${ }^{133}$ character of photography against its instrumentalisation as an apparatus of governmental capture and spectacular exposure. ${ }^{34}$

The explicit depoliticising intention of the removal of Mohr's captions - for which After the Last Sky serves as a remarkable kind of restitution, a commendable overcompensation - links back very strongly to a mainstay of critical reflection on photography. Back in 1931, in A Short History of Photography', Benjamin had mused: 'It has been said that "not he who is ignorant of writing but ignorant of photography will be the illiterate of the future." But isn't a photographer who can't read his own pictures worth less than an illiterate? Will not captions become the essential component of pictures? ${ }^{\text {?5 }}$ In the midst of his collaboration with Brecht, as well as of his engagement with Sergei Tretyakov and the Soviet conception of the 'author as producer', he had declared: 'What we must demand from the photographer is the ability to put such a caption beneath his picture as will rescue it from the ravages of modishness and confer upon it a revolutionary use value.. ${ }^{36}$ This is indeed what Brecht had done in his recaptioning of World War Two news and propaganda in War Primer during his own exile. ${ }^{37}$ When critical theorists and historians of photography like Allan Sekula built on the intuitions of Benjamin and Brecht in 1970s, they too reflected on the significance of the textual (and its absence) in either capturing photography for ideological usages or treating its contingency and indeterminacy as an occasion for interpretation, contestation and critical montage. In removing the captions from Mohr's pictures the UN authorities were reducing his record of Palestinian life to the same kind of generic, 'sentimental humanism' that Sekula so brilliantly excoriated with reference to Edward Steichen's 
Family of $\mathrm{Man}^{38}$ - an exhibition which, incidentally, featured a justifiably famous, if decontextualised image of a Palestinian woman in a posture of protest. ${ }^{39}$

Lastly, in the Israeli and Palestinian context, we can think of the admirable effort of re-captioning the photographic archive of dispossession carried out by the Israeli political theorist of photography Ariella Azoulay in her From Palestine to Israel: $A$ Photographic Record of Destruction and State Formation, 1947-1950 and her earlier exhibition Act of State. ${ }^{40}$ Not only does Azoulay's patient, political and at times poetic supplementing of images from Zionist archives with critical and descriptive texts allow her to counter strategies of invisibility crucial to dispossession - where 'facts on the ground' have an inextricable visual dimension - she also highlights the bitter irony of how dispossession itself was a violent act of renaming, and, as it were, re-captioning and re-titling land, to remove the traces of history, habitation and people. A picture entitled 'Umm al-Zinat' in Chapter 3 of From Palestine to Israel, 'Architecture of Dispossession, Destruction and Gaining Ownership', shows two young men (Jewish immigrants from Yemen) planting a sign for the new town of Elyakim. The indistinct landscape in the background - unpaved roads, what look to be a few small new houses, some stones - reveals something else to Azoulay's eye: 'If you look at the piles of earth along the road, you can see that they're mixed with the rubble of Umm al-Zinat's 209 houses, crushed into bits after 1,470 were expelled'. She also cites Ben-Gurion: 'Since the places referred to no longer exist, the names of these places are also eliminated' (though as Azoulay astutely notes, this posed a problem for the chronicle of Zionist conquest, since battles could only be named after the Arab sites of Jewish victory). ${ }^{41}$

The question of text or caption as it relates to representation has a further bearing on After the Last Sky. One of the things that the plurality, and non-linear montage, of different textual registers allows Said is a shift from theoretical and historical reflections to more introspective, and indeed self-critical ones, which notably complicates what we might mean by 'representation'. The question of land and peasantry (and less intensely of manual labour, all of them alien to Said's class and experience, as he acknowledges) is very salient here too, as the author of Orientalism avers his own tendency to repeat the colonial-Orientalist operation and treat the Palestinian peasantry as somehow immobile (this could also be linked to his ambivalent descriptions of the bazaars depicted by Mohr as 'untidy, undocumented, unexpressive' - where the last two terms jar with the images). In their 'silence', and seeming perennial repetition, images of peasant life are particularly prone to reinforce a visual prejudice that Said registers in his own attitude: 'I continue to perceive a population of poor, suffering, occasionally colourful peasants, unchanging and collective'. ${ }^{42}$

The fact that this perception is 'mythic' as Said recognizes, does not stop it from colouring his own experience. Though captions and text are necessarily incomplete, partial, perspectival, the potentially dangerous indeterminacy of photographs renders them necessary. For meaning or truth to burst through the montage, the patient if scattered dialogue of image and text is inescapable. Reflecting on two seemingly indistinguishable images of peasant women walking in file on dust roads - one captioned 'Irbid, 1950', the other 'Near Mount Carmel, 1979' - Said writes: 'in themselves these photographs are silent; they seem saturated with a kind of inert being that outweighs anything they express; consequently they invite the embroidery of explanatory words. What's more, in our heads legends arise unbidden which further obscure the photographs'. ${ }^{43}$ At least one step in the direction of struggling against these legends, these reflexive ideologies, in which certain images seem to directly connote 'the Orient', the 'eternal peasant' and so on, is the realisation that such photographs - especially when accompanied by the wrong caption, by clichés that create an effect of redundancy between text and image (that is obviously a peasant, that is obviously a terrorist, etc.) - 
are in a sense the product of something like a secondary alienation. As Said reflects:

these accumulated representations add up to a frighteningly direct correlative of what the photographs depict: alienated labor, as Marx called it, work done by people who have little control of either the product of their labor or their own laboring capacity. After such a recognition, whatever bit of exotic romance that might attach to these pictures is promptly blown away. As the process of preserving the scenes, photographic representation is thus the culmination of a sequence of capturings. Palestinian peasants working are the creatures of half a dozen other processes, none of which leaves these productive human beings with their labor intact. 44

Though we may wonder how promptly or definitively the romantic connotations, our immediate visual association of certain posture and scenes with certain civilisation prejudices (about labour, land, use, possession), are indeed 'blown away', we can note that in such passages Said lends authority to the idea that representations can repeat, enact or indeed encapsulate political violence, legal dispossession and economic alienation alike. There is surely much to justify such a view - especially when we think of the myriad visual practices critical to dispossession and occupation (Azoulay's book, for instance, contains some remarkable photographs secretly taken before 1948 by Haganah scouts, themselves hiding under Palestinian keffiyehs, to prepare the dispossession of Palestinian villages). But there is a welcome complexity to Said's reflections, as well as to his collaboration with Mohr, absent in much image work in and on Palestine.

Said does not simply ascribe to fashionable homilies about the violence of representation, and though he is the first to highlight the short-circuits between an aesthetic regime of representation and a political one - he even writes of the Palestinians and the PLO: 'as a people, they can be represented ${ }^{15}-$ he never elides the two. In fact the tension between political and visual representation is one of the drivers of After the Last Sky. Said's response to the representational predicament of the Palestinians is formulated in a more programmatic way in the introduction to the book, detailing how history, politics and experience have shaped the form of his collaboration with Mohr:

\footnotetext{
Since the main features of our present existence are dispossession, dispersion, and yet also a kind of power incommensurate with our stateless exile, I believe that essentially unconventional, hybrid and fragmentary forms of expression should be used to represent us. What I have quite consciously designed, then, is an alternative mode of expression to the one usually encountered in the media, in works of social science, in popular fiction. It is a personal rendering of the Palestinians as a dispersed national community - acting, acted upon, proud, tender, miserable, funny, indomitable, ironic, paranoid, defensive, assertive, attractive, compelling. ${ }^{46}$
}

This fragmentation is also determined by the reality and the intent of 'double vision', both in the sense of a self-reflection of Palestinian life through the eyes of a nonPalestinian photographer, and in terms of a representational experience akin in a way to Du Bois's idea of 'double consciousness', and symptomatically marked by Said's shifts between the register of the 'I', the 'you' and the 'we'.

As abrupt as these shifts are, I feel they reproduce the way 'we' experience ourselves, the way 'you' sense that others look at 'you', the way, in your solitude, you feel the distance between where 'you' are and where 'they' are. ${ }^{47}$

The representational predicament of Palestine and Palestinians, which After the Last Sky responds to with such passion and nuance, is also one that has continued to attract, absorb and confound visual artists (and has also, it should be noted, at times been used in instrumental or superficial ways). All have intervened in an ideological and 
political economy of images in which, as Said insisted, Palestinians were both over- and under-represented, turned (very often) into frozen caricatures or distortions or (more rarely, today almost never) into stereotyped revolutionary icons. In Georges DidiHuberman's terms what Said was responding to was a kind of dialectic of over- and under-exposure. As the French art historian and theorist asks: 'What can be done so that peoples are exposed to themselves and not to their own disappearance?'. ${ }^{48}$

In an explicitly political, revolutionary vein, this was the predicament of filmmakers like Jean-Luc Godard and Jean-Pierre Gorin, or Masao Adachi and Koji Wakamatsu, drawing on the traditions of formalist, militant cinema - from Sergei Eisenstein and Dziga Vertov onwards - to make visual documents of the Palestinian struggle, works of open propaganda for groups like Fatah or the PFLP. Already in films like Adachi and Wakamatsu's remarkable PFLP-Japanese Red Army: Declaration of World $W a r{ }^{49}$ however, the problem of representation is foregrounded. The Palestinian revolutionary Leila Khaled, her iconic face transformed by plastic surgery, is featured in an off-screen narration and in the depiction of her living quarters; refugee camps in Lebanon are explored through eerily abstract shots - reminiscent of Lucio Fontana paintings - of the bullet holes, possibly left by proxy Israeli forces, through masonry and corrugated iron. Godard returned with his partner Anne-Marie Mieville to the footage of his collaboration with Gorin, Jusqu'a la Victoire (Until Victory), which had been brutally interrupted by the 'Black September' 1970 massacre in Jordan of Palestinian refugees and militants, including almost all who had appeared in the film. They decided to treat the footage and its representation of revolution as the material for a complex exercise in montage and self-criticism, which, intercut with the daily banalities and oppressions of a depoliticised working-class existence in France, gave the film its title Ici et Ailleurs (Here and Elsewhere). The effort was oriented towards demonstrating the fallacies of the linear sequence of revolutionary liberation and people's war that Godard had originally wanted to impose on the struggle; the haunting of the images by deaths both unexpected and foretold; the way in which the film-makers had perhaps colluded in a kind of revolutionary theatricality that silenced the less spectacular experiences of Palestinian life and struggle, thus failing to escape the chains of iconic and replaceable images that define the spectacular economy of capitalism. The text - in this case the voice-over rather than the caption - had drowned out the voices of the Palestinian themselves, turning images into clichés (one of the film's most remarkable moments comes at the end, as Godard and Miéville belatedly translate what the Fatah militants were actually saying in the original footage). We could also recall here Said's reflections regarding the external gaze on Palestine, when he writes of 'the contrast between their [non-Palestinian, Western] urge to record and systematise and our [Palestinian] passive, scattered incoherence. ${ }^{150}$ And it is indeed this problem that the artist and theorist Oraib Toukan has acutely brought into relief in her response to these revolutionary representations: the 'land' or 'nation' of Palestine such films represent is invariably that of the refugee camps and guerrilla havens from which Palestinian fighters are operating, which is to say it is never Palestine 'itself. ${ }^{51}$ The militant here is a territorial elsewhere.

We can also reflect on how in the more recent period the photographic depictions of Palestine by the French photographer Sophie Ristelhueber - images of tense formalistic restraint, and seeming monotony, which attend to the traces of occupation but decide to leave any Palestinian life beyond the frame - have been taken by Jacques Rancière as emblematic of a kind of political photography that would not be prey to the stereotypical visual rhetoric of the 'intolerable image'. ${ }^{52}$ Modulating a scepticism about images (and about social or political realism tout court) which would be the simple reaction to the excessive political faith previously accorded them, Rancière turns to Ristelhueber's $W B$ (for West Bank - the restraint is even present in the title) to 
write the following, which we reproduce here as a testament to how the question of Palestine continues to be linked, both politically and aesthetically, to that of representation:

The images of art do not supply weapons for battles. They help sketch new configurations of what can be seen, what can be said and what can be thought and, consequently, a new landscape of the possible. But they do so on condition that their meaning or effect is not anticipated. This resistance to anticipation can be seen illustrated by a photograph taken by the French artist Sophie Ristelhueber. In this picture, a pile of stone is harmoniously integrated into an idyllic landscape of hills covered with olive trees, a landscape similar to that photographed by Victor Berard to display the permanence of the Mediterranean of Ulysses' voyages. But this little pile of stones in a pastoral landscape takes on meaning in the set it belongs to. Like all the photographs in the series 'WB' (West Bank), it represents an Israeli roadblock on a Palestinian road. Sophie Ristelhueber has in fact refused to photograph the great separation wall that embodies the policy of a state and is the media icon of the 'Middle Eastern problem'. Instead she has pointed her lens at these small roadblocks which the Israelis have built on the country roads with whatever means available. And she has invariably done so from a bird's-eye view, from a viewpoint that transforms the block of the barriers into elements of the landscape. She has photographed not the emblem of the war but the wounds and scars it imprints on a territory. In this way she perhaps effects a displacement of the exhausted affect of indignation to a more discreet affect, an affect of indeterminate effect - curiosity, the desire to see closer up. ${ }^{53}$

What are the effects of this iconoclasm, of this desire - in the wake of an exhaustion with clichés and icons - to remain with the 'minor' traces of occupation? Is the caption 'WB' enough? Is this formalist politics - which is evidently also the product of an outsider, a spectator (Ristelhueber even calls upon, in the back cover of WB, the famous passage in Lucretius' De Rerum Natura, about the spectator gazing at a shipwreck in a combination of horror and enjoyment of safety) - one that could be put into critical dialogue with After the Last Sky?

\section{Conclusion: Representing Bedouin Dispossession}

One way of answering these questions is to turn one last time to the ongoing dispossession of the Bedouin in the Naqab, and to how it has elicited two of the most arresting and reflexive of contemporary photographic enterprises.

The first is the work of Fazal Sheikh. A rightly celebrated portraitist working especially in conditions of violent displacement, particularly in refugee camps from Kenya to Pakistan, Sheikh decided to take to aerial photography to photograph the traces of the dispossession of the Naqab Bedouin by the Israeli state in his series Desert Bloom. In so doing, he both repurposed a practice that has been enduringly associated with military sight and instrumental abstraction ${ }^{54}$ - not to mention colonial knowledge - but also gave the 'bird's eye view' a much more determinate 'truth-function' than the one allowed by Rancière's reading of Ristelheuber in terms of 'indeterminate effect'. As Eyal Weizman draws out in his rich catalogue essay for Sheikh's trilogy Erasure, of which Desert Blooms form part, aerial photography played a critical role in the legal contestations over Bedouin property with which we began. The traces that such photography (whether archival or contemporary) registers - and which attracted the antagonistic interpretive energies of analysts, activists and lawyers - conjoin the historical, the military, the governmental, the legal and the ecological (Weizman is particularly illuminating on the 'representation' of the 'aridity line' as a key factor in the settler-colonisation of the Naqab). ${ }^{55}$ So as to address a 'scar just beneath the surface', Sheikh has undertaken a multi-level photo-work, testament to the labour that goes into reversing, however precariously, systematic and strategic processes of erasure. As he reflects: 'My experience of the spaces that had been either wilfully erased - dismantled, destroyed and the stones 
taken away - or subsumed beneath forests, was astonishing: this idea that, years on, I could visit the site of a village and find that it is today an extraordinary forest, and unless you look with a critical eye it is virtually impossible to find the remnants of the past. ${ }^{56}$ Part of this work involves moving away from lived experience, moving above it the better to articulate the on-going struggles on the ground. Here the temporary distance from portraiture and documentary is not part of a generic 'critique of representation', but an effort to address the sometimes invisible, or rather difficult to see, reality of what is nonetheless a ubiquitous process of dispossession. Sheikh's reflections are ones that should also inform our legal and political imaginary: 'Sitting there in that tent, looking across the expanse of what had been the village and seeing these troughs, this scarification rendered on the land, I suddenly had the idea that it was important to see that from the perspective of a distance, from above, in order to understand the context of what I was looking at on the ground'..$^{7}$

The second work that we want to touch upon in conclusion is that of the Palestinian photographer, Ahlam Shibli, who has both prolonged the project of registering and giving aesthetic form to dispossession - so central to Said and Mohr's enterprise - with an insistent focus on the Bedouin, in projects such as Goter, Trackers and Unrecognised, the latter bearing precisely on the unrecognised Bedouin villages discussed above.$^{58}$ Shibli's work been interpreted as having absorbed many of the critiques of the evidence or transparency of political representation. As the art theorist TJ Demos has put it: 'By revealing the obstructions of the image, Shibli reveals the representational condition of photography that it produces the effects it displays, plays an active role in the construction of its subjects, and constitutes an opaque surface whose coding can only be ambiguous, a condition that disqualifies interpretation based on referential certainty'. ${ }^{59}$ The 'testimonial' character of Shibli's photographs is more oblique, especially when it comes to the activity of portraiture, than Mohr's work. Figures are blurred, faces concealed, bodies withdrawn, while the materiality of dispossession is nevertheless powerfully present. As Demos notes, a caution towards the social and political claims of documentary is here combined with an unwillingness to embrace the modish view of photography as a purely 'fictional construct'. What we are faced with then is a reflexive reinvention of the documentary 'that refuses to sever its ties to lived experience, even while [Shibli] engages the representational complexities of her medium'. ${ }^{60}$ We could add that the ways in which the specific experience of non-recognition and precariousness of the Bedouin is brought into relief in Shibli's work marks her critical handling of photographic representation as much more determinately political than the figural restraint of Ristelheuber, as celebrated by Rancière. Read along After the Last Sky, and Said (and Mohr's) 'double vision', such work can also take us beyond a formal critique of the photographic condition, to think in more complex and committed ways about the politics of representation and also about how 'referential certainty' might not be the primary target of criticism today, especially when dispossession is at stake.

The resonance between Shibli's work and Said and Mohr's endeavour is even stronger when it comes to the politics of captioning and text. When her work Goter (a Bedouin expression which is the trace of the British colonial injunction 'Go there!', inscribing the colonial continuities noted above) was shown at the Tel Aviv Museum, the catalogue was redacted to remove any reference to the occupation of the Naqab, as well as to the establishment of unrecognised villages and the poisoning of Bedouin agriculture by the Israelis. Dayan's notorious declaration - 'Without coercion but with governmental direction... this phenomenon of the Bedouins will disappear ${ }^{61}$ - was also removed. The photographer's own eloquent response to the curators' complicity in this erasure is worth quoting at length, providing as it does a fitting conclusion to our reflections after Said and Mohr. It starkly demonstrates how, in the words of Sara Khinski's perceptive 
analysis: 'Palestinian citizens of the State of Israel are issued with selective and temporary passes into the artworld but have no sovereignty over their own culture'. ${ }^{62}$ But it also combatively asserts the contemporary endurance and relevance of the project to represent and counter dispossession, alongside a much stronger claim to political and historical truth than Demos himself allows, while hinting at the lessons that an often clichéd discourse on the critique of representation can draw from the conjuncture of settler colonialism in Israel/Palestine:

The Museum's director wrote: 'The hardships the Bedouin of the Negev have faced in the process of adapting to life-style changes is integral to the history and birth pangs of Israel.' I told him that his interpretation of my work was wrong and misleading. My photographs are not about a process of 'adaptation' to modern changes, but rather about state imposed violent changes. I never talked about 'hardships', I talked about state repression. Not to mention the appropriation of the 'hardships' to the 'birth pangs of Israel'. There is clearly a link between the Bedouin problems and the State of Israel, which has nothing to do with birth pangs, but rather with the outcome of that birth. Should the State of Israel had not been born, the Negev Bedouins would have had time to deal with issues such as their lifestyle. [The director] further wrote: "The juxtaposition of sublime infinite spaces with a detailed focus on their dwellings, i.e. "architecture without architects", demonstrates the conflict between man and place, at times serene and at times unbearably difficult.' I am not a tour guide or an anthropologist. I don't photograph landscapes or life-styles. In my photographs, I try to present the repression, not the sublime magic of landscape and lifestyle. The Bedouin way of life was linked to a place, to an economy based mainly on the land, and they are losing all these due to the robbery of their land by the State. How can you use a problematic terminology such as 'architecture without architects', concerning their destruction by the State! 63

\title{
Notes on Contributors
}

\section{Brenna Bhandar is Senior Lecturer in Law at SOAS, University of London.}

\author{
Alberto Toscano is Reader in Critical Theory at Goldsmiths, University of \\ London.
}

\section{Notes}

A version of this paper was first delivered in the context of the exhibition SPACE \& GAZE: Conversations with Jean Mohr \& Edward Said in Palestine, organised by the Methods Lab, Department of Sociology, Goldsmiths, University of London (November 2013-June 2014). We are grateful to Nirmal Puwar and Mariam Motamedi-Fraser for the invitation to engage with the work of Said and Mohr. Thanks also to Fazal Sheikh and Eyal Weizman for sharing their work with us.

\footnotetext{
${ }^{1}$ David Harvey, The New Imperialism (Oxford: Oxford University Press, 2003).

${ }^{2}$ Frantz Fanon, 'Concerning Violence', in The Wretched of the Earth (London: Penguin, 2001). See also, for a more contemporary reflection and further references, David Lloyd, Irish Times: Temporalities of Modernity (Dublin: Field Day, 2008), 10-21.

${ }^{3}$ Edward W. Said, with photographs by Jean Mohr, After the Last Sky (London: Faber and Faber, 1986).

${ }^{4}$ Edward W. Said, Reflections on Exile: And Other Literary and Cultural Essays (London: Granta, 2000), 151.

5 The Israeli Supreme Court issued judgment in May 2015, denying the appeal.

${ }^{6}$ Alexandre (Sandy) Kedar, Oren Yiftachel and Ahmad Amara (2012). 'Questioning the "Dead

(Mewat) Negev Doctrine”: Property Rights in Arab Bedouin Space’ (Hebrew), Law and Government 12 (2012): 7-147. These authors have explicitly compared what they term the "dead negev doctrine" to the way in which the doctrine of terra nullius was used to dispossess Indigenous people in Australia.

7 The following is a useful typology of Ottoman land designations: 'Private land, mulk: right of full
} 
ownership and alienation, as well as right to the usufruct of the land. State land, miri: suitable for agricultural use where the ultimate owner is the state but the usufruct belongs, in most cases, to individuals. ... Public land, waqf: reserved and immobilized, for some public (e.g. charitable) purpose, and usually leased, as it was in the past. So-called "dead", unreclaimed land, mawat: mainly used for grazing under common property regimes, and often a grey area with political undertones'. Nadia Forni, 'Land Tenure Policies in the Middle East', FAO Bulletin 2003/1. Available at: http://www.fao.org/docrep/005/y8999t/y8999t0f.htm\#TopOfPage. Last accessed 16 September 2014.

${ }^{8}$ For a substantial body of work on the concept of the material witness see Forensic Architecture Forensis: The Architecture of Public Truth (Berlin: Sternberg Press, 2014)

${ }^{9}$ Here are some indicative passages: 'On behalf of the Plaintiffs an expert opinion was submitted, written by Mr. Shlomo Ben Yosef, an expert in the interpretation of aerial photographs.... The opinion relies on aerial photographs taken in 1945. The expert claimed that a Bedouin rural settlement was in existence but it became evident that it is a thin spread extending over an area of about 30,000 dunams on which there were isolated dwellings. ... Contrary to the opinion expressed by Prof. Yiftachel whose view was that the 1945 aerial photographs pointed to the existence of intensive cultivation covering most of the plots in El Araqib (page 13 of the first expert report), in the questioning of Mr. Ben Shlomo an entirely different picture emerged of very partial cultivation, to say the least. It is not clear from this data as to how Prof. Yiftachel saw intensive cultivation covering most of the Araqib plots - puzzling. The conclusion is that no basis of evidence has been adduced in respect of intensive cultivation, nor in 1945'. (Suleiman El-Uqbi et al v The State of Israel (March 2012) Civil Case File Nos. paras 18, 19) While the judge deemed that Yiftachel's interpretation culpably coloured the expert's interpretation of the visual evidence of settlement, their own profoundly ideological standards of the objective tests for settlement go unquestioned.

10 Ariella Azoulay, From Palestine to Israel: A Photographic Record of Destruction and State Formation, 1947-1950 (London: Pluto, 2011), 9.

${ }^{11}$ Said and Mohr, 104.

12 Abu Sitta's Atlas of Palestine provides a formidable and exhaustive topographic record of dispossession, which provides an indispensable complement to Said's account. See Salman H. Abu Sitta, Atlas of Palestine, 1917-1966 (London: Palestine Land Society, 2010).

13 Said and Mohr, After the Last Sky, 104-5.

${ }^{14}$ Rosemary Sayigh, The Palestinians: From Peasants to Revolutionaries (London: Zed Books, 2007 [1979]).

15 Said and Mohr, 19.

16 Said and Mohr, 13.

${ }^{17}$ Kedar et al., 'Questioning the "Dead (Mewat) Negev Doctrine"; Suhad Bishara and Haneen Naamnih, 'Nomads Against Their Will: the attempted expulsion of the Arab Bedouin in the Naqab: the example of Atir-Umm Al-Heiran', Adalab- Legal Centre for Arab Minority Rights (2011). Available at: http://www.adalah.org/eng/publications/Nomads\%20Against $\% 20$ their\%20Will\%20English\%20pdf $\% 20 \mathrm{f}$ inal.pdf. Last accessed 16 September 2014.

18 'We should transform the Bedouins into an urban proletariat... Indeed, this will be a radical move which means that the Bedouin would not live on his land with his herds, but would become an urban person... His children would be accustomed to a father who wears trousers, does not carry ashabaria [the traditional Bedouin knife] and does not search for vermin in public. This would be a revolution, but it may be fixed within two generations. Without coercion but with governmental direction... this phenomenon of the Bedouins will disappear'. Cited in Jillian Kestler D’Amours, 'The end of the bedouin', Le monde diplomatique (August 2012), available at: http://mondediplo.com/2012/08/06bedouin\#nb2

19 The Restricted Areas - i.e. areas of land which were not explicitly appropriated by the State in 1953 (Land Acquisition (Validation of Acts and Compensation) Law - were not included in development plans for the area. See Abu-Saad Amara and Oren Yiftachel (eds.) Indigenous (In)Justice: Human Rights Law and Bedouin (Cambridge, MA: Harvard University Press, 2013).

20 Said and Mohr, 23.

${ }^{21}$ Patrick Wolfe, Settler Colonialism: The Politics and Poetics of an Ethnographic Event (London: Continuum, 1999), 388.

22 See the final report at: http://www.trc.ca/websites/trcinstitution/index.php?p=890

${ }^{23}$ For an engagement with Robert Meister's important critique of transitional justice and its temporality, see Alberto Toscano, 'The Tactics and Ethics of Humanitarianism', Humanity: An International Journal of Human Rights 5, no. 1 (2014): 123-47.

${ }^{24}$ Said and Mohr, 38.

25 'The main battle in imperialism is over land, of course; but when it came to who owned the land, who had the right to work and settle on it, who kept it going, who won it back, and who now plans its future these issues were reflected, contested, and even for a time decided in narrative'. Edward W. Said, Culture \& Imperialism (New York: Vintage, 1994), p. xiii.

${ }^{26}$ Said and Mohr, 82. 
${ }^{27}$ Edward W. Said, Covering Islam: How the Media and the Experts Determine How We See the Rest of the World (New York: Vintage, 1997).

${ }^{28}$ Said and Mohr, 3.

${ }^{29}$ John Berger, 'Jean Mohr: A Sketch for a Portrait', in Jean Mohr and John Berger, At the Edge of the World (London: Reaktion, 1999).

${ }^{30}$ John Berger and Jean Mohr, A Seventh Man, new ed. (London: Verso, 2010); John Berger and Jean Mohr, Another Way of Telling (New York: Vintage, 1995).

${ }^{31}$ Said, Reflections on Exile, 149. Gerald Manley Hopkins (1844-1889) was an English poet, who said cites at several points across his writings.

32 Said, Reflections on Exile, 150.

${ }^{33}$ Said, Reflections on Exile, 151.

${ }^{34}$ It is also of interest - though somewhat tangential to this discussion - that in that same review Said sympathetically criticised Berger for a possibly misplaced hope in the recovery of subjectivity through photography, as well as for not articulating how such an image practice could fit in a broader counterhegemonic challenge to dominant ideologies.

35 Walter Benjamin, 'A Short History of Photography', in Alan Trachtenberg (ed.), Classic Essays on

Photography (New Haven: Leete’s Island Books, 1980), 215.

36 Walter Benjamin, 'The Author as Producer', in Understanding Brecht, trans. Anna Bostock (London: Verso, 1998), 95.

${ }^{37}$ Bertolt Brecht, War Primer, ed. John Willett (London: Libris, 1998).

38 Allan Sekula, 'The Traffic in Photographs', Art Journal 41, no. 1 (1981): 15-25.

${ }^{39}$ Monique Berlier, 'The Family of Man: Readings of an Exhibition', in Bonnie Brennen and Hanno Hardt (eds.), Picturing the Past: Media, History \& Photography (Champaign: University of Illinois Press, 1999), 226-7.

40 Ariella Azoulay, Atto di stato. Palestina-Israele, 1967-2007. Storia fotografica dell'occupazione, ed. Maria Nadotti. (Milan: Bruno Mondadori, 2008).

41 Azoulay, From Palestine to Israel, 116.

${ }^{42}$ Said and Mohr, 88.

43 Said and Mohr, 92.

${ }^{44}$ Said and Mohr, 93.

45 Said and Mohr, 121.

46 Said and Mohr, 6.

${ }^{47}$ Ibid.

48 Georges Didi-Huberman, Peuples exposés, peuples figurants. L’Oeil de l'histoire, 4 (Paris: Les Éditions de Minuit, 2012), 11.

${ }^{49}$ The film is freely available at: http://ubu.com/film/adachi_red.html

50 Said and Mohr, 96.

51 Oraib Toukan, 'A lecture in three parts, in between the odd discussion', in Ala Younis (ed.) Tin Soldiers (Gwangju: Gwangju Biennial, 2012). Also available at: http://oraibtoukan.com/printed_matter_files/Oraib\%20Toukan $\% 20$ Gardening\%20a $\% 20$ Pitiless $\% 20$ Mou ntain.pdf

52 Jacques Rancière, The Emancipated Spectator (London: Verso, 2009), 83-105,

${ }_{53}$ Rancière, The Emancipated Spectator, 103-4.

54 Allan Sekula, 'The Instrumental Image: Steichen at War', Artforum 14, no. 4 (1975), 26-35.

${ }^{55}$ Eyal Weizman, 'The Conflict's Shoreline', in Fazal Sheikh, The Erasure Trilogy (Göttingen: Steidl, 2015).

${ }^{56}$ Fazal Sheikh, 'Fazal Sheikh Interviewed by Shela Sheikh', in This Place, ed. Charlotte Cotton (London: Mack, 2014). 118.

57 'Fazal Sheikh Interviewed by Shela Sheikh', 119.

${ }^{58}$ For information on these projects, see http://www.ahlamshibli.com/Work/Work.htm

59 T.J. Demos, The Migrant Image: The Art and Politics of Documentary during Global Crisis (Durham, NC: Duke University Press, 2013), 140-1. See also Berger's thoughtful remarks on Shibli's work: John Berger, 'Looking Carefully - Two Women Photographers', in Hold Everything Dear: Dispatches on Survival and Resistance (New York: Pantheon, 2007), 133-45; John Berger, 'A Nomadic Discretion' (2003), available at: http://www.ahlamshibli.com/texts/nomadic.htm

${ }^{60}$ Demos, The Migrant Image, 127.

${ }^{61}$ See Jillian Kestler D'Amours, 'The end of the bedouin'.

${ }^{62}$ Sara Khinski, 'The Politics of "Goter": The Poetics of Protest in National Israeli Art', Third Text 20, nos. 3 and 4 (2006), 416.

${ }^{63}$ Shibli, quoted in Khinski, "The Politics of "Goter", 413. 